Ritrýnd grein birt 11. apríl 2019

\title{
Börn sem eru sein til máls: Áhrif pjálfunar á orðaforða barns á priðja ári
}

\author{
Marta Eydal, Jóhanna T. Einarsdóttir, \\ Porlákur Karlsson og Póra Sæunn Úlfsdóttir
}

\begin{abstract}
- Um höfundana

About the authors

Heimildir

Tilgangur rannsóknarinnar var að skoða áhrif pjálfunar á orðaforða barns á priðja ári, sem seint var til máls. Einn pátttakandi varí rannsókninni. Við upphaf rannsóknarinnar var hann 30 mánaða, notaði rúmlega 160 orð og var ekki farinn að tengja saman orð í setningar. Dátttakandinn var valinn af hentugleika. Djálfunin var byggð á fyrirlögn fyrir fram ákveðinna markorða sem pjálfuð voru bæði á fjölbreyttan hátt og með ákefð. Einnig voru valin samanburðarorð sem ekki voru pjálfuð. Djálfunin fór fram tvisvar í viku í leikskóla barnsins og voru pjálfunartímar 14 talsins. Niðurstöður leiddu í ljós að almennur orðaforði barnsins, sem mældur var með staðlaða málproskaprófinu Orðaskil, jókst yfir pjálfunartímabilið umfram pað sem vænta mátti vegna almenns proska. Mælingar sýndu að barnið notaði markorðin meira en samanburðarorðin, bæði heima og í pjálfunartímum, og að notkun á orðunum jókst eftir pví sem leið á pjálfunina. Sú aukning sem varð á orðaforða barnsins hélst mánuði eftir að íhlutun lauk. Mikilvægt er að bera kennsl á seinkun í málproska eins snemma og kostur er. Degar búið er að bera kennsl á barn sem seint er til máls parf í framhaldi að veita pví viðeigandi örvun eða íhlutun, en pessi rannsókn bendir til að slík pjálfun geti haft góð áhrif. Sambærileg rannsókn hefur ekki verið gerð áður á Íslandi.
\end{abstract}

Efnisorð: Málproski, börn sem eru sein til máls, orðaforði, snemmtæk íhlutun.

\section{Inngangur}

Málproski er mikilvægur proskapáttur og er í mótun allt frá fæðingu og fram á fullorðinsár. Dekking á tungumálinu er undirstaða samskipta og pátttöku í nútíma samfélagi. Enn fremur byggist lestrarnám á tungumálinu og lestur er undirstaða alls bóklegs náms (Einarsdóttir, Björnsdóttir og Símonardóttir, 2016; Strong, Silver, Perini og Tuculescu, 2014). Grunnur að málfærni einstaklings sem lagður er á fyrstu árunum er gríðarlega mikilvægur fyrir framtíðina. Fyrstu árin í lífi hvers barns eru tími mótunar og framfara, m.a. í taugaproska, en á pessum aldri eru börn mjög móttækileg fyrir umhverfi sínu. Mikilvægt er að allir peir sem koma að málefnum barna geti borið kennsl á frávik í málproska. Degar komið hefur í ljós að málproski barns er ekki innan dæmigerðra marka parf að veita pví viðeigandi aðstoð. Í pessari grein verður athugað hvort pjálfun orðaforða, sem byggist á fjölbreytileika og ákefð, leiði til bættrar mállegrar hæfni hjá barni á priðja ári sem seint er til máls. 


\section{Börn sem eru sein til máls}

Börn sem sein eru til máls eru mjög misleitur hópur en oftast er um að ræða börn á aldrinum 24 til 35 mánaða, sem eru sein í málproska miðað við jafnaldra, og pá sérstaklega í tjáningu orða. Ekki er hægt að útskýra seinan málbroska barnanna með páttum eins og heyrnarskerðingu eða einhverfu og pau eru of ung til að fá greininguna málproskaröskun (Alt, Meyers, Oglivie, Nicholas og Arizmendi, 2014). Erfitt er að skilgreina barn sem er seint til máls fyrir tveggja ára aldur par sem mikill fjölbreytileiki kemur fyrir í orðaforðatileinkun hjá börnum á pví aldursskeiði (Tsybina og Eriks-Brophy, 2007).

Um tveggja ára aldur er oftast hægt að koma auga á hvort barn er seint til máls eða ekki. Í enskumælandi löndum er barn skilgreint sem seint til máls ef pað notar færri en 50 orð og/ eða ef barnið er ekki farið að mynda tveggja orða setningar við 24 mánaða aldur (Rescorla, 1989). Í rannsókn Rescorla, Mirak og Singh (2000) kom í ljós að meðalfjöldi orða í orðaforða enskumælandi barna sem sein voru til máls var 18 orð við 24 mánaða aldur, 89 orð við 30 mánaða aldur og 195 orð við 36 mánaða aldur. Til samanburðar var orðaforði peirra barna sem ekki voru sein til máls 150-180 orð við 24 mánaða aldur. Stærð orðaforðans er augljóslega einn af peim páttum sem snemma greinir börn sem sein eru til máls frá börnum með dæmigerðan málproska. Desmaris, Sylvestre, Meyer, Bairati og Rouleau (2008) komust jafnframt að pví í kerfisbundnu yfirliti á rannsóknum að börn sem voru sein til máls voru ekki jafn málgefin og jafnaldrar með dæmigerðan málproska og höfðu færri hljóð í hljóđaskrá sinni. Átti petta við um bæði samhljóð og sérhljóð. Dá hafa rannsóknir staðfest að uppbygging atkvæða er einfaldari hjá börnum sem sein eru til máls (Carson, Klee, Carson og Hime, 2003). Detta einkennist af pví að opin atkvæði, samsett af stöku sérhljóði eða samhljóði og sérhljóði, eru í meirihluta. Talið er að draga megi pá ályktun að hljóðfræði- og hljóðkerfisfræðileg hæfni barna sem eru sein til máls sé slakari en jafnaldra með dæmigerðan málproska (Desmaris o.fl., 2008).

Hlutfall barna sem sein voru til máls við tveggja ára aldur var um 15\% samkvæmt yfirlitsgrein Desmaris o.fl. (2008). Zubrick, Taylor, Rice og Slegers (2007) tala um 13-19\% barna í pessu samhengi og er раð svipað niðurstöðum Horwitz o.fl. (2003) par sem 13,5\% barna á aldrinum 18-23 mánaða voru með seinkun í máltjáningu og 17,5\% barna á aldrinum 30-36 mánaða. Rannsókn Reilly o.fl. (2009) leiddi í ljós að 19,7\% barna við tveggja ára aldur höfðu seinkun í máltjáningu. Detta voru mun fleiri börn en skilgreind eru með málproskaröskun við fimm ára aldur. Tomblin o.fl. (1997) komust að pví að algengi málproskaröskunar meðal fimm ára barna væri um 7\%. Nýleg rannsókn leiddi í ljós svipaðar niðurstöður hjá fjögurra til fimm ára börnum eða 7,6\% algengi (Norbury o.fl., 2016). Dað er pví allstór hópur barna sem er seinn til máls við tveggja ára aldur en nær að tileinka sér tungumálið síðar á leikskólaárunum.

\section{Hvaða börn eru í áhættuhópi?}

Sá páttur sem virðist hafa hvað mest áhrif er kyn, en rannsóknir á algengi hafa leitt í ljós að hlutfall drengja sem eru seinir til máls er mun hærra en hlutfall stúlkna (Zubrick o.fl., 2007). Erfðapátturinn er einnig mjög sterkur og hafa í ýmsum rannsóknum verið skoðuð tengsl erfða og málproskaraskana (Bishop, North og Donlan, 1995; Bishop, Price, Dale og Plomin, 2003; Rice, 2012). Pá hefur oft verið fjallað um að menntun móður og samfélagsleg staða hafi áhrif á málproska barna. Niðurstöður rannsókna á pessum efnum eru nokkuð misvísandi (Zubrick o.fl., 2007). Almennt er pó talið að menntun móður og samfélagsleg staða séu mikilvægir áhrifapættir í málproska barna, par sem pessir pættir hafa áhrifá pað mállega umhverfi sem börn alast upp við (Desmaris o.fl., 2008). Í nýlegri rannsókn Hammer og félaga (2017) reyndist samfélagsleg staða vera sá páttur, fyrir utan pað að vera drengur, sem hafði mest áhrif á pað hvort börn voru sein til máls eða ekki við tveggja ára aldur. Samfélagsleg staða var skoðuð með tilliti til menntunar, atvinnu og tekna foreldra. 
Vigil, Hodges og Klee (2005) rannsökuðu hvort munur væri á mállegu ílagi foreldra barna með dæmigerðan málproska og foreldra barna sem voru sein til máls en með pví er átt við hvernig og hversu mikið foreldrar töluðu við börn sín. Niðurstöður leiddu í ljós að mælanlegir pættir mállega ílagsins sem börnin fengu voru svipaðir, en pað sem pau mældu var fjöldi segða, fjöldi orða og meðallengd segða í orðum. Með segð er átt við allt pað sem sagt er í einu lagi og getur verið frá einni málsgrein niður í eitt orð (Höskuldur Dráinsson, 1995). Meðallengd segða mælir hversu mörg orð eru notuð аð meðaltali í einni setningu eða segð (Jóhanna T. Einarsdóttir og Álfhildur Porsteinsdóttir, 2015). Vigil o.fl. (2005) komust hins vegar að pví að pví að samræðutækni foreldranna í hópunum tveimur var ólík. Foreldrar barna sem voru sein til máls svöruðu börnum sínum sjaldnar og brugðust á annan hátt við tali barna sinna en hinir foreldrarnir. Í stað pess að fylgja frumkvæði barnsins, skiptu foreldrarnir um umræðuefni. Telja höfundar petta geta stafað af pví að foreldrarnir hafi verið að reyna að hvetja börn sín til aukinnar tjáningar með pví að skipta um umræðuefni, sem aftur getur haft aukið álag í för með sér fyrir börnin. Sýnt hefur verið fram á tengsl milli álags á foreldrum og seinkunar í máltjáningu barna (Desmaris o.fl., 2008). Dess háttar álag á foreldri getur verið tilkomið vegna pátta sem tengjast barninu eða vegna pátta sem tengjast foreldrinu sjálfu. Degar foreldrar eru undir slíku álagi getur pað haft áhrif á næmni peirra í samskiptum við barn sitt og pannig haft neikvæð áhrif á málproska pess.

\section{Framvinda og horfur}

Börn sem sein eru til máls eru ekki endilega talin vera í áhættu varðandi að próa með sér málproskaröskun pó pað geti verið ákveðin vísbending um slíkt (Bishop og Edmundson, 1987; Rescorla, 2011). Einkenni málbroskaröskunar hjá börnum eru erfiðleikar með tungumál sem orsakast ekki af pekktum taugafræði-, vitsmuna-, skynjunar- eða tilfinningalegum páttum. Erfiðleikarnir geta haft áhrif á próun orðaforða, málfræði og samtalshæfni pessara barna, en pau geta verið klár og heilbrigð að öðru leyti (Ervin, 2001). Rannsóknir hafa leitt í ljós að börnum með málproskaröskun gengur verr félagslega og námslega pegar pau eldast en peim sem eru með dæmigerðan málproska (Conti-Ramsden, Durkin, Simkin og Knox, 2009; Durkin og ContiRamsden, 2007) og má í pessu samhengi nefna lestrarerfiðleika (Snowling, Bishop og Stothard, 2000).

Rannsókn Thal og Tobias (1992) á börnum á aldrinum 18-28 mánaða leiddi í ljós að 60\% barnanna, sem voru sein í máltjáningu, náđu sér á strik að ári liðnu. Í rannsókn Dale, Price, Bishop og Plomin (2003) reyndust 44\% peirra barna, sem höfðu fengið pá greiningu að vera sein til máls við tveggja ára aldur, vera með málproskaröskun við priggja ára aldur. Rescorla, Roberts og Dahlsgaard (1997) rannsökuðu börn sem voru á aldrinum 24-31 mánaða og voru sein í máltjáningu. Við priggja ára aldur voru börnin marktækt lakari en samanburðarhópur jafnaldra á öllum prófum sem lögð voru fyrir pau. Tsybina og Eriks-Brophy (2007) bentu á í umfjöllun sinni um enskumælandi börn sem eru sein til máls og ná sér á strik, að pað virtist vera ákveðið mynstur í málproska pessara barna pegar fram liðu stundir. Đótt einkenni peirra væri að vera með slakan orðaforða miðað við jafnaldra pegar pau væru mjög ung, gætu pau náð jafnöldrum sínum á pví sviði pegar pau yrðu eldri. Degar pau væru orðin eldri birtust erfiðleikar peirra frekar á sviði setningafræði og beygingar- og orðmyndunarfræði.

Í samantekt Rescorla (2011) kemur fram að börn sem hafa verið greind sem sein til máls á unga aldri eru yfirleitt innan eðlilegra marka á málbroskaprófum við 6-7 ára aldur. Prátt fyrir pað eru pau marktækt slakari á pessum prófum en jafnaldrar sem ekki voru seinir til máls. Tungumálið heldur pví áfram að vera veikleiki hjá pessum börnum pótt pau nái sér á strik og mælist innan eðlilegra marka. Í samantektinni kemur enn fremur fram að skimun fyrir seinkun í máltjáningu, við 18-35 mánaða aldur, geti gegnt mikilvægu hlutverki par sem hugsanlega sé um víðtækari vanda að ræða. Fjallar hún sérstaklega um röskun á málskilningi í pessu samhengi par sem börn með seinkun í málskilningi, frekar en í máltjáningu, eru í hættu á að eiga við náms-, hegðunarog tilfinningavanda seinna meir. 
Börn sem eru sein til máls eru nokkuð stór hópur sem fær ekki endilega sérstaka pjónustu eða íhlutun, m.a. vegna ungs aldurs. Í pessu samhengi má benda á að skimuná tal- og málproskafrávikum á Íslandi fer fram í reglubundnu eftirliti ung- og smábarnaverndar heilsugæslustöðva en pað er gert í 2;6 og 4;0 ára skoðun (Embætti landlæknis, 2013). Hægt er að gera ráð fyrir pví að börn undir 2;6 ára aldri sem eru sein til máls fái hvorki pjónustu né íhlutun par sem ekki hefur verið skimað markvisst fyrir frávikum í málproska hjá pessum aldurshópi.

\section{Íhlutun}

Degar talað er um snemmtæka íhlutun er átt við pegar börnum með proskafrávik, eða í hættu á að vera með frávik í proska, er veitt sérstök örvun eða íhlutun. Sú íhlutun miðar að pví að ýta undir proska pessara barna. Í umfjöllun Ramey og Ramey (1998) um snemmtæka íhlutun er bent á að íhlutun sem byrjar snemma á proskaskeiði barns og stendur yfir í lengri tíma geri almennt meira gagn en íhlutun sem byrjar seinna og stendur styttra yfir. Einnig skiptir ákefð meðferðar máli, t.d. hversu oft íhlutun á sér stað, en meiri ákefð leiðir af sér jákvæðari niðurstöður.

Tiltölulega fáar rannsóknir hafa verið gerðar á íhlutun fyrir börn á aldrinum 24-36 mánaða sem eru sein til máls. Cable og Domsch (2011) fjölluðu um slíkar rannsóknir í yfirlitsgrein sinni. Tilgangur peirra var að kanna hvort íhlutun hjá pessum hópi barna skilaði sér í bættri mállegri getu. Mismunandi pjálfunaraðferðir voru notaðar í peim rannsóknum sem teknar voru til athugunar í yfirlitinu. Málleg geta var skoðuð með ólíkum hætti, t.d. með stöðluðum málproskaprófum, með athugunum á meðallengd segða í samtölum eða með fjölda lærðra markorða. Markorð eru pau orð sem markvisst er unnið með í pjálfun. Niðurstöður yfirlitsins leiddu í ljós að meðferð fyrir börn sem eru sein til máls er áhrifarík leið til bættrar frammistöðu á stöðluðum málproskaprófum og til bættrar meðallengdar segða. Í nokkrum nýrri rannsóknum, sem ekki voru teknar fyrir í yfirliti Cable og Domsch (2011), var unnið með orðaforðaíhlutun hjá börnum sem sein voru til máls. DeVeney, Cress og Reid (2014) notuðu tvær mismunandi aðferðir við að kenna börnum á aldrinum 25-33 mánaða orð, en báðar byggðust á markvissri notkun ákveðinna markorða. Reyndust báðar aðferðirnar áhrifaríkar til kennslu á orðum. Butler, Brown og Woods (2014) notuðu rafbækur í orðaforðapjálfun með börnum á aldrinum 25-36 mánaða. Allir pátttakendur bættu skilning sinn á peim orðum sem lögð voru fyrir og fjórir af fimm pátttakendum bættu tjáningu sína á orðunum. Alt og félagar (2014) veittu börnum á aldrinum 23-29 mánaða orðaforðaíhlutun par sem áhersla var lögð á að kenna orðin á fjölbreyttan hátt og með ákefð. Íhlutunin reyndist áhrifarík og hafði ekki aðeins áhrif á pau orð sem pjálfuð voru heldur einnig á almennan orðaforða. Niðurstöður ofangreindra rannsókna benda til pess að íhlutun fyrir ung börn sem eru sein til máls sé áhrifarík leið til að bæta málproska peirra.

Hvað stöðuna á Íslandi varðar má benda á niðurstöður könnunar sem gerð var í tengslum við skýrslu um stöðu barna og ungmenna með tal- og málproskaröskun (Hrafnhildur Ragnarsdóttir, Jóhanna Einarsdóttir, Marta Gall Jörgensen og Dóra Sæunn Úlfsdóttir, 2012). Pátttakendur könnunarinnar voru foreldrar og aðstandendur barna með málbroskafrávik, fagfólk sem starfaði með börnum með málproskafrávik eða kom að málefnum peirra og fulltrúar og starfsmenn sveitarstjórna. Niðurstöður könnunarinnar voru margpæettar en $90 \%$ pátttakenda töldu brýnt að bæta pjónustu við börn með málproskafrávik innan skólakerfisins. Einn af mikilvægustu páttunum sem tengdust pjónustunni varðaði snemmtæka íhlutun, en 98\% pátttakenda töldu mikilvægt að auka áherslu á fyrirbyggjandi starf og snemmtæka íhlutun.

\section{Námskenningar um orðaforða}

Námskenningar skýra hvernig einstaklingar tileinka sér reglur eða mynstur úr umhverfi sínu. Flókin ferli liggja að baki orðaforðanámi og koma par ýmsir pættir við sögu. Barn parf að einangra orð úr peim orðaflaumi sem pað heyrir, eða að pví er beint, og átta sig á pví til hvaða hlutar petta tiltekna orð vísar (Alt o.fl., 2014). Рá parf pað að geta yfirfært pekkingu sína á aðra 
hluti sem orðið á einnig við um. Einnig parf barnið að æfa sig 1 að nota rétta hreyfiferla talfæra til pess að mynda orð.

Ómeðvitað nám á sér stað pegar einstaklingur er ekki sérstaklega að reyna að læra. Alt, Meyers og Ancharksi (2012) fjölluðu í yfirlitsgrein sinni um undirstöðuatriði ómeðvitaðs náms hjá börnum með dæmigerðan málproska og hvernig hægt væri að tengja pessi atriði við íhlutun hjá börnum með röskun í málproska. Höfundar komust að pví að peir pættir sem skiptu mestu máli voru fjölbreytileiki og flækjustig. Detta pýðir að umhverfið parf að vera fjölbreytt, t.d. að barn heyri tal fleiri en einnar manneskju til pess að tryggja fjölbreytt hljóðfræðilegt ílag. Pá skiptir fjölbreytileiki í notkun hluta máli, t.d. að barn sjái ólíkar gerðir bíla ef „bíll“ er orðið sem verið er að læra. Mállegt flækjustig getur haft áhrif par sem flóknar setningar eru meira örvandi en stök orð. Tíðni og fjöldi/skammtur skiptir einnig máli en tíðni getur pýtt t.d. hversu oft barn heyrir ákveðið orð og fjöldi/skammtur getur býtt t.d. hversu oft barn fær íhlutun eða hvernig henni er dreift yfir ákveðinn tíma. Betra er að barn heyri fleiri orð sem dreifast yfir marga tíma en að pað heyri færri orð í einum tíma. Hugtakið „,nám í fjölbreyttum aðstæðum“) vísar til ákveðinnar námstækni í orðaforðanámi ungra barna sem felur í sér að læra orð, p.e. að átta sig á til hvaða hlutar ákveðið orð vísar, í margs konar samhengi (Smith og Smith, 2012).

Framangreindar námskenningar fjalla í megindráttum um hversu mikilvægt er að ómeðvitað nám hjá börnum eigi sér stað á náttúrulegan hátt, byggist á fjölbreyttum aðferðum og sé krefjandi. Petta á við um börn með dæmigerðan málproska en á einnig og jafnvel sérstaklega við um börn með röskun í málproska.

\section{Fjölbreytileiki og ákefð í íhlutun}

Líkt og fjallað var um hér að framan er fjölbreytileiki einn af peim páttum sem skoðaður hefur verið í rannsóknum á orðaforðanámi barna. Fjölbreytileiki í orðaforðapjálfun getur m.a. falist í fjölbreyttu mállegu samhengi. Má par nefna mikilvægi pess að tala ekki við barnið í símskeytastíl heldur tala við pað í heilum setningum, en niðurstöður rannsóknar Bredin-Oja og Fey (2014) studdu ekki notkun símskeytastíls í pjálfun barna með seinkun í máltjáningu. Pá gaf rannsókn á ungbörnum vísbendingar um mikilvægi fjölorða ílags í málproska barna, en fjölorða ílag pýðir аð börn heyri ekki aðeins stök orð heldur orð í samfelldu tali (Saffran, Aslin og Newport, 1996). Fjölbreytileiki getur einnig falist í notkun fjölbreyttra hluta sem vísa til pess orðs sem pjálfað er. Perry, Samuelson, Malloy og Schiffer (2010) komust að pví að 18 mánaða gömlum börnum gekk betur en börnum í samanburðarhópi að yfirfæra pekkingu sína úr orðaforðapjálfun yfir á nýja hluti, einum mánuði eftir pjálfun, ef notaðir höfðu verið fjölbreyttir hlutir í pjálfuninni. Einnig lærðu pau ný orð hraðar eftir pjálfunina en börnin í samanburðarhópi. Fjölbreyttir hlutir vísa hér til pess að notaðar voru margar mismunandi gerðir af sama hlutnum til pess að kenna orð, t.d. voru sýndar fötur af ólíkri lögun, stærð og í mismunandi litum pegar orðið „fata“ var lagt fyrir. Í rannsókn Alt og félaga (2014) var börnum, sem voru sein til máls, veitt orðaforðaíhlutun sem byggðist á hugmyndum um ómeðvitað nám í fjölbreyttum aðstæðum. Fjölbreytnin fólst í pví að pau orð sem notuð voru í pjálfuninni voru lögð fyrir á setningafræðilega fjölbreyttan hátt, p.e. á mismunandi stað innan setninga í samfelldu máli. Einnig voru orðin lögð fyrir á marga ólíka vegu, t.d. með mismunandi leikföngum.

Annar páttur sem skiptir máli í orðaforðapjálfun er ákefð pjálfunar. Í yfirlitsgrein sinni bentu Alt og félagar (2012) á að börn með seinkaðan málproska pyrftu líklega fleiri pjálfunartíma en börn með dæmigerðan málproska og einnig meiri ákefð í hverjum tíma, p.e. aukna tíðni peirra pátta sem pjálfaðir væru í tímum. Með pví er átt til dæmis við að börn með seinan málproska purfa að heyra orð sem verið er að kenna peim mun oftar en börn sem eru með dæmigerðan málproska. Alt og félagar (2014) notuðu í sinni rannsókn viðmið um ákefð byggð á upplýsingum úr rannsókn Camarata, Nelson og Camarata (1994). Camarata o.fl. (1994) fundu út að börn með málproskaröskun purftu að meðaltali að heyra 64 fyrirmyndir af pví sem verið var að pjálfa pau í, sem var reyndar málfræði en ekki orðaforði, áður en pau gátu myndað pað sjálfsprottið. 
Í áðurnefndri rannsókn Alt og félaga (2014) fólst ákefðin í pví að hvert orð sem markvisst var pjálfað kom fyrir a.m.k. 64 sinnum hjá pjálfara í hverjum meðferðartíma. Íhlutunin, par sem unnið var bæði með fjölbreytileika og ákefð, reyndist áhrifarík og hafði ekki aðeins áhrif á pau orð sem pjálfuð voru heldur einnig á almennan orðaforða.

\section{Mælingar á orðaforða}

Mikilvægt er að geta mælt orðaforða með viðurkenndum aðferðum. Með orðaforðamælingum er hægt að sjá hvar einstaklingur er staddur í samanburði við jafnaldra, eða í samanburði við sjálfan sig pegar um er að ræða mælingar yfir ákveðið tímabil. Hægt er að mæla orðaforða með mismunandi aðferðum en misjafnt er hvaða aðferð hentar best hverju sinni. Ein leið til að mæla hann er með sérstökum orðaforða- eða málproskaprófum. Đá eru einnig til mælitæki sem byggjast á svörum foreldra, t.d. ef um mjög ung börn er að ræða. Par má nefna málproskaprófið MacArthur Communicative Development Inventory. Íslenska útgáfan af pví er málproskaprófið Orðaskil. Баð er ætlað börnum á aldrinum eins og hálfs til priggja ára (Elín Döll Dórðardóttir, 1998). Раð mælir orðaforða barna og vald peirra á íslensku beygingakerfi og setningagerð og er staðlað fyrir íslenskt pýði. Prófið er lagt fyrir foreldra og merkja peir við orð og setningagerðir sem peir hafa heyrt barnið sitt segja. Réttmæti íslenska prófsins hefur verið kannað og reynst vera mjög gott (Thordardottir og Weismer, 1998).

Баð er ekki svo að aðeins sé hægt að nota stöðluð orðaforðapróf pegar meta á orðaforða barna. Marulis og Neuman (2010) fjölluðu um í safngreiningu sinni að einnig væru notuð mælitæki í rannsóknarlegum tilgangi sem búin væru til af höfundum sérstaklega fyrir hverja og eina rannsókn. Dessi mælitæki reynast betur en pau sem notuð eru til að mæla almennan orðaforða, pví pau mæla einmitt pau orð sem verið er að vinna með í hverri rannsókn fyrir sig. Dess konar mælingar gera höfundum rannsókna kleift að svara peirri spurningu hvort börnin hafi lært pað sem peim var kennt. Dar sem mælitæki sem búin eru til af höfundum takmarkast af pví að pau kanna aðeins pau orð sem verið er að vinna með er nauðsynlegt að nota einnig aðrar mælingar, s.s. stöðluð próf. Með pví að leggja fyrir stöðluð próf sést hver málfærni einstaklingsins er í samanburði við meðalgetu jafnaldra.

Með framangreindum aðferðum er hægt að mæla orðaforða ungra barna, t.d. í rannsóknarlegum tilgangi, og fylgjast pannig með framförum yfir ákveðið tímabil.

\section{Rannsóknarspurningar}

Markmið rannsóknarinnar er að veita barni á priðja ári, sem seint er til máls, orðaforðapjálfun í 14 skipti og meta árangurinn af peirri pjálfun. Djálfunin byggist á fjölbreytni og ákefð og felur í sér fyrirlögn fyrir fram ákveðinna markorða. Leitast verður við að svara eftirfarandi spurningum:

- Eykst almennur orðaforði barnsins eftir 14 pjálfunartíma, umfram pað sem vænta má vegna almenns proska?

- Lærir barnið fleiri markorð en samanburðarorð?

- Ef aukning verður á orðaforða barnsins, helst sú aukning mánuði eftir að íhlutun lýkur?

\section{Аðferð}

\section{Dátttakandi}

Einn pátttakandi var í rannsókninni og var hann valinn af hentugleika. Hann purfti að uppfylla pau skilyrði að vera 24-35 mánaða, hafa íslensku að móðurmáli, að báðir foreldrar teldu hann vera seinan til máls og einnig að leikskóli teldi hann seinan til máls. Enn fremur purfti hann að falla undir almenn viðmið að vera talinn seinn til máls. Yfirleitt er miðað við að börn sem eru sein 
til máls séu að minnsta kosti fyrir neðan 10. hundraðsmark í orðaforða miðað við jafnaldra. Enn fremur að barn sé ekki farið að tengja saman tvö orð og/eða noti færri en 50 orð við 24 mánaða aldur. Pátttakandinn var drengur sem var 30 mánaða pegar pjálfunin hófst og verður hann hér eftir kallaður Gunnar. Hann uppfyllti öll skilyrði til pátttöku. Ekki voru til staðar áhyggjur af almennum, óyrtum vitsmunaproska hjá Gunnari, en pað var pó ekki prófað sérstaklega. Við upphaf pjálfunar var hann ekki farinn að mynda tveggja orða setningar og orðaforði hans var 166 orð. Á málproskaprófinu Orðaskil eru drengir við 30 mánaða aldur við 10. hundraðsmark með 282 orð í orðaforða sínum sem er rúmum 100 orðum meira en Gunnar hafði.

\section{Efni}

Við pjálfunina voru notuð ýmiss konar leikföng og annar efniviður sem hentaði peim orðum sem valin voru til pjálfunar. Ef umrædd leikföng vöktu ekki áhuga Gunnars var brugðist við með pví að hafa eitthvað sem honum pótti spennandi og pað tengt við orðin sem pjálfuð voru á einn eða annan hátt. Leitast var við að hafa efniviðinn sem fjölbreytilegastan pannig að áhugi Gunnars héldist í gegnum hvern pjálfunartíma. Ef lest var markorð pá voru notaðir ólíkir hlutir til að pjálfa orðið lest, s.s. bók um lest, púsl með myndum af lestum, lest sem hægt var að keyra, myndir af lestum o.s.frv. Рað kom fljótt í ljós hvaða dót Gunnari pótti mest spennandi og var skipulag pjálfunarinnar aðlagað að áhuga hans.

\section{Val á orðum}

Við val á orðum var haft samráð við foreldra, en peir völdu orð sem peir töldu mikilvægt fyrir Gunnar að geta notað í sínu daglega lífi og samskiptum. Pessi orð tengdust m.a. áhugasviði Gunnars eða voru orð sem mikilvægt var fyrir Gunnar að kunna (t.d. nafnið hans). Foreldrar hans voru pess fullvissir að orðin sem voru valin væru ekki hluti af virkum orðaforða Gunnars. Valin voru fimm markorð og fimm samanburðarorð og mynduðu pau eins konar orðapör. Samanburðarorðin purftu að hæfa við markorðin og helst líkjast peim í lengd, orðflokki og einnig merkingarlega. Orðapörin voru eftirfarandi og er markorðið talið fyrst og pá samanburðarorðið; 1) nafn barns - nafn frænda 2) brunabíll - löggubíll 3) jógúrt - kjöt 4) leikskóli - bókasafn 5) lest - vörubíll.

\section{Rannsóknarsnið}

Við framkvæmd rannsóknarinnar var notað einliðasnið. Dað hentar vel pegar meta skal árangur af pjálfun eða íhlutun hjá fáum pátttakendum. Dað er einnig hægt að nota pegar pátttakandi er aðeins einn líkt og í pessu tilviki. Einliðasnið hentar vel til að gera samanburð á frammistöðu einstaklings, t.d. fyrir og eftir íhlutun (Horner o.fl., 2005).

\section{Framkvæmd pjálfunar}

Djálfunaraðferðin byggðist á aðferð Alt og félaga (2014). Haft var samband við höfund rannsóknarinnar sem veitti nákvæmari lýsingu á pví hvernig orðin voru pjálfuð. Voru pessar upplýsingar notaðar í upphafi meðferðar til að leggja línurnar fyrir bjálfunina. Hún fór fram í leikskóla Gunnars, alltaf í sama sérkennsluherberginu. Djálfunartímar voru 14 talsins og fóru að jafnaði fram tvisvar í viku. Djálfunin tók yfir níu vikna tímabil. Markorðin voru alls fimm en prjú orð voru pjálfuð í öðrum tímanum og tvö í hinum. Hvor orðahópur var tekinn fyrir samtals sjö sinnum. Í upphafi hvers tíma var próf úr markorðum og samanburðarorðum lagt fyrir. Eftir prófun voru markorðin lögð fyrir, yfirleitt í sömu röð í hverjum tíma. Stundum var peim pó að einhverju leyti blandað saman. Meðferðin var ílags-miðuð sem pýddi að ekki var gerð krafa um að Gunnar segði neitt í tímunum frekar en hann vildi. Ílag rannsakanda var pað sem áhersla var lögð á. Allir pjálfunartímar voru teknir upp á myndband. 


\section{Meðferðarheldni}

Farið var yfir myndbandsupptökur og skoðað hvort viðmiðum um ákefð, p.e. hversu oft markorðin komu fyrir hjá rannsakanda í hverjum tíma, hefði verið framfylgt. Alt og félagar (2014) miðuðu við að hvert markorð kæmi a.m.k. 64 sinnum fyrir í hverjum tíma. Detta viðmið var einnig notað í pessari rannsókn. Hvað fjölbreytileika varðar var í rannsókn Alt og félaga miðað við að pjálfarar notuðu fimm mismunandi aðferðir við að leggja fyrir hvert markorð í hverjum tíma. Detta var einnig notað sem viðmið í pessari rannsókn, en líkt og rætt var hér að framan réði áhugi barnsins ferðinni. Đá var einnig miðað við í rannsókn Alt og félaga að hvert markorð kæmi fyrir á mismunandi stöðum innan setninga og var peim viðmiðum fylgt eftir eins og hægt var í pessari rannsókn.

\section{Mælingar}

Mælingar fóru fram áður en pjálfun hófst, jafnt og pétt á meðan á pjálfun stóð, eftir að pjálfun lauk og að lokum voru viðhaldsmælingar gerðar um mánuði eftir að pjálfun lauk. Pær mælingar sem rannsakandi gerði fóru fram á leikskóla Gunnars og mælingar foreldra fóru fram heima hjá honum.

Í Töflu 1 má sjá yfirlit yfir pær mælingar sem voru gerðar.

Tafla 1. Yfirlit mælinga

\begin{tabular}{lll}
\hline Grunnskeiðsmæling & $\bullet$ & Orðaskil \\
Mæling gerð í hverjum pjálfunartíma & $\bullet$ & Próf úr markorðum og samanburðarorðum \\
Mæling gerð um leið og pjálfun lauk & $\bullet$ & Orðaskil \\
$\begin{array}{l}\text { Mælingar gerðar um mánuði eftir að } \\
\text { pjálfun lauk }\end{array}$ & $\cdot$ Orðaskil \\
& $\begin{array}{l}\text { Próf úr markorðum og samanburðar- } \\
\text { orðum }\end{array}$ \\
\hline
\end{tabular}

\section{Orðaskil}

Orðaskil er eins og fram hefur komið íslenska útgáfan af enska málproskaprófinu MacArthur Communicative Development Inventory og er ætlað börnum á aldrinum eins og hálfs til priggja ára (Elín Döll Dórðardóttir, 1998). Dað mælir orðaforða barna og vald peirra á íslensku beygingakerfi og setningagerð og er staðlað fyrir íslenskt pýði. Prófið er lagt fyrir foreldra og merkja peir við orð og setningagerðir sem peir hafa heyrt barnið sitt segja. Orðaskil skiptist í tvo meginhluta, en sá fyrri kannar orðaforða og sá seinni setningar og málfræði. Sé barn undir 10. hundraðsmarki eða meira en 1,28 staðalfrávikum fyrir neðan meðaltal er pað talið vera seint til máls samkvæmt handbók sem fylgir prófinu. Orðaskil var lagt fyrir Gunnar á grunnskeiði til að meta málproska hans fyrir íhlutun og staðfesta að um seinkun í málproska væri að ræða. Reyndist hann vera meira en einu og hálfu staðalfráviki fyrir neðan meðaltal jafnaldra í orðaforða, og undir 10. hundraðsmarki, sem gefur vísbendingu um frávik í málbroska. Par sem Gunnar var ekki farinn að tengja saman tvö orð í setningar var seinni hluta prófsins sleppt í pað skiptið. 


\section{Próf úr markorðum og samanburðarorðum}

Í upphafi hvers pjálfunartíma og mánuði eftir að íhlutun lauk voru markorðin og samanburðarorðin prófuð. Petta var gert á pann hátt að Gunnari voru sýndar myndir af orðunum og reynt að laða fram svör hjá honum t.d. með pví að spyrja „Hvað er petta?“ eða „Hver er petta?“. Gunnari voru sýndar myndirnar í tilviljunarröð í hvert skipti og pað hvort hann svaraði spurningunum eða ekki skráð niður. Pau markorð og samanburðarorð sem Gunnar sagði síðan sjálfsprottið í tímunum voru einnig skráð niður. Dá var foreldrum sent skráningarblað í upphafi hverrar bjálfunarviku og peir beðnir að skrá öll pau markorð og/eða samanburðarorð sem Gunnar sagði sjálfsprottið yfir vikuna. Dessar mælingar á markorðum og samanburðarorðum voru sérstaklega gerðar fyrir rannsóknina sem hér um ræðir og pví ekki staðlaðar mælingar heldur mat rannsakanda og foreldra hverju sinni.

\section{Mælingar og hlutverk foreldra}

Hlutverk foreldra í pessari rannsókn var tvípætt. Annars vegar að gefa í upphafi lýsingu á vanda barnsins og staðfesta áhyggjur af seinkun í málproska. Hins vegar að taka pátt í peim mælingum sem gerðar voru. Foreldrar fylltu út málproskaprófið Orðaskil prisvar sinnum; p.e. ádur en íhlutun hófst, eftir að íhlutun lauk og mánuði eftir að íhlutun lauk. Pá purftu foreldrar að skrá pau markorð og samanburðarorð sem komu fyrir hjá Gunnari yfir tímabilið. Foreldrum var sent skráningarblað í upphafi hverrar meðferðarviku par sem peir áttu að skrá yfir vikuna öll pau markorð og/eða samanburðarorð sem Gunnar notaði utan meðferðartímanna, en útskýrt var fyrir foreldrum að peir áttu aðeins að skrá sjálfsprottið tal Gunnars. Foreldrar skiluðu blöðunum útfylltum í byrjun hverrar viku og fengu pá nýtt blað. Í rannsókn Alt og félaga (2014) áttu foreldrar að skrá allt sjálfsprottið tal barnsins yfir vikuna, en fæst barnanna í peirri rannsókn voru farin að herma eftir orðum. Í peirri rannsókn sem hér um ræðir skráđu foreldrar aðeins pau samanburðar- og markorð sem komu fyrir sjálfsprottið hjá Gunnari yfir vikuna, par sem hann var farinn að herma mikið eftir orðum.

\section{Úrvinnsla}

Gögnum úr öllum mælingum var safnað á rafrænt form jafnóðum og síðan unnið úr peim á viðeigandi hátt. Degar búið var að taka niðurstöður saman var peim svo safnað í Microsoft Excel skjal og pað forrit notað til að gera myndir sem lýsa niðurstöðunum myndrænt. Sjónrænni greiningu var beitt við að skoða gögnin en pað er sú aðferð sem helst er notuð við að greina gögn í einliðasniði (Guðrún Árnadóttir og Porlákur Karlsson, 2003). Aðferðin byggist á pví að meta hvort munur sé á skráningargildum á einu skeiði pegar pau eru borin saman við skráningargildi á öðru skeiði.

\section{Niðurstöður}

Hér á eftir verður greint frá niðurstöðum allra mælinga. Fyrst verður fjallað um niðurstöður úr málproskaprófinu Orðaskil, síðan verða markorðin og samanburðarorðin skoðuð.

\section{Orðaskil}

Orðaskil var lagt fyrir áđur en íhlutun hófst, strax eftir að íhlutun lauk og mánuði eftir að íhlutun lauk. Á Mynd 1 má sjá niðurstöður úr kafla I-A, Orðaforðagátlista. 


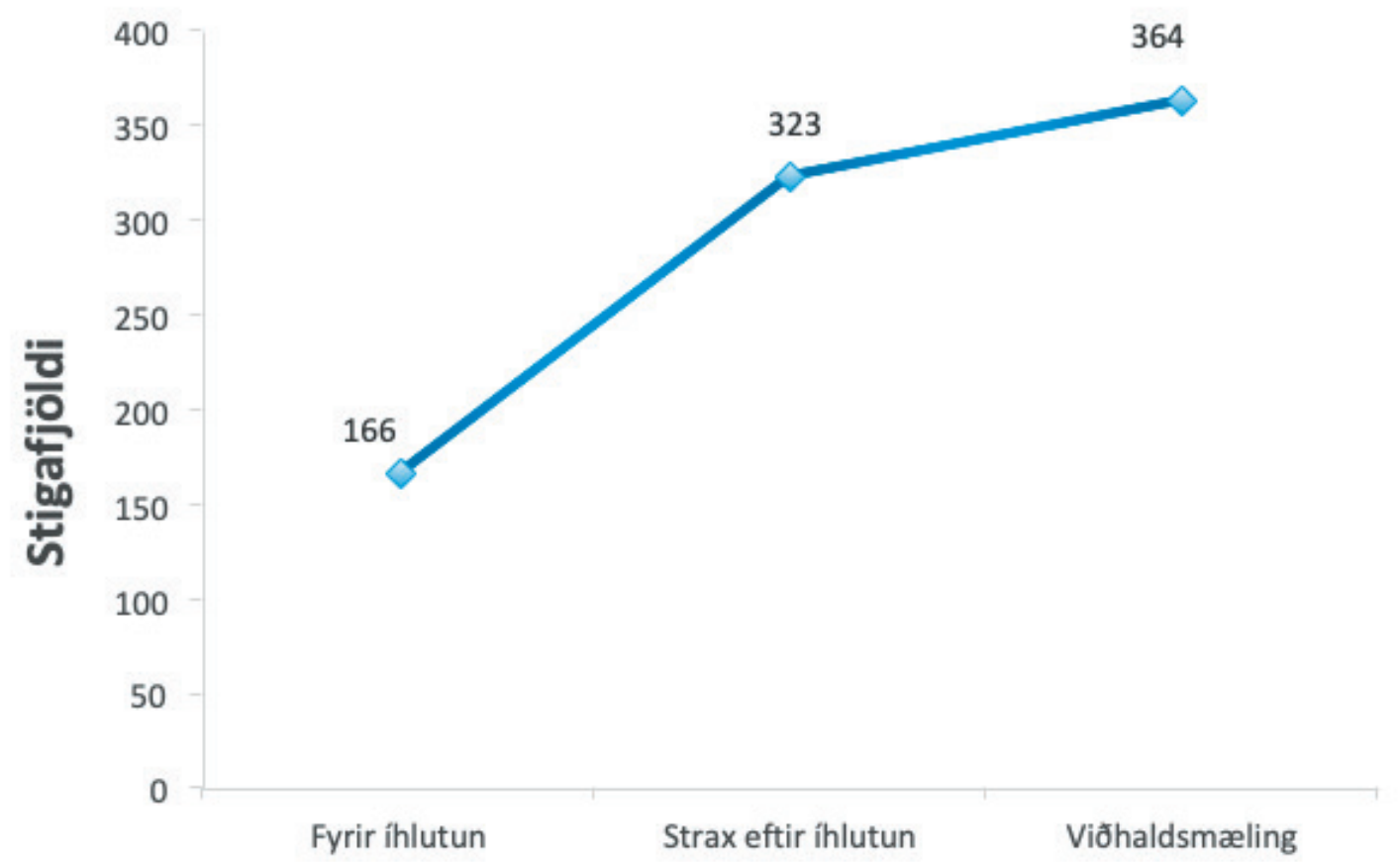

Mynd 1. Útkoma úr kafla I-A: Orðaforðagátlisti

Fyrir íhlutun, pegar Gunnar var 30 mánaða gamall, fékk hann 166 stig úr pessum kafla prófsins sem er 1,86 staðalfrávikum fyrir neðan meðaltal drengja á sama aldri og undir 10. hundraðsmarki. Meðalorðafjöldi drengja á aldrinum 30-31 mánaða er 429 stig með staðalfrávikið 141,5. Strax eftir íhlutun, pegar Gunnar var 32 mánaða, fékk hann 323 stig á orðaforðagátlistanum sem er 1,23 staðalfrávikum fyrir neðan meðaltal drengja á sama aldri, en fyrir ofan 10. hundraðsmark. Meðalorðafjöldi drengja á aldrinum 32-33 mánaða er 477 stig með staðalfrávikið 125,5. Fjórum vikum eftir íhlutun fékk Gunnar 364 stig, pá 33 mánaða gamall, sem er rétt tæplega einu staðalfráviki fyrir neðan meðaltal drengja á sama aldri og fyrir ofan 10 . hundraðsmark.

Að meðaltali bætti Gunnar við sig 17,4 orðum á viku meðan á pjálfuninni stóð eða samtals 157 orðum. Eftir að pjálfun lauk og par til viðhaldsmælingar voru gerðar bætti Gunnar við sig 10,3 orðum að meðaltali á viku eða 41 orði á fjórum vikum. Degar petta er skoðað með tilliti til pess hve mörgum mánuðum Gunnar bætti við sig í málproska má gróflega áætla að hann hafi bætt við sig um 4-5 mánuðum frá upphafi íhlutunar par til íhlutun lauk. Detta má finna út með pví að skoða á hvaða aldursbili Gunnar var, miðað við meðaltöl, við upphaf íhlutunar. Sá stigafjöldi staðsetti hann á milli tveggja aldursbila; 20-21 mánaða par sem meðaltalið er 126 stig og 22-23 mánaða par sem meðaltalið er 202 stig. Strax eftir íhlutun, pegar stigafjöldinn var kominn upp 1 323 orð, var Gunnar nánast kominn upp í aldursbilið 26-27 mánaða, par sem meðaltalið er 326 stig. Degar viðhaldsmælingar voru gerðar um mánuði eftir íhlutun var Gunnar svo næstum kominn upp á næsta aldursbil fyrir ofan, 28-29 mánaða par sem meðaltalið er 379 stig, en hann náđi pví pó ekki alveg.

\section{Markorð og samanburðarorð}

Rannsakandi lagði fyrir Gunnar próf úr markorðum og samanburðarorðum í hverjum pjálfunartíma. Ekki fengust niðurstöður úr beim prófunum. Detta stafar af pví að ekkert peirra orða sem prófuð voru komu fram hjá Gunnari, ýmist vegna pess að hann gat ekki sagt pau eða vegna pess að hann vildi ekki taka pátt pegar hann var spurður. Hins vegar voru pau markorð og samanburðarorð sem Gunnar sagði sjálfsprottið í pjálfunartímum skráð niður. Var pað gert eftir á pegar myndbandsupptökur úr pjálfunartímum voru skoðaðar. Par sem Gunnar sagði einungis markorð sjálfsprottið í tímunum en ekki samanburðarorð pá eru aðeins markorðin skráð. Dessar niðurstöður má sjá á Mynd 2. 


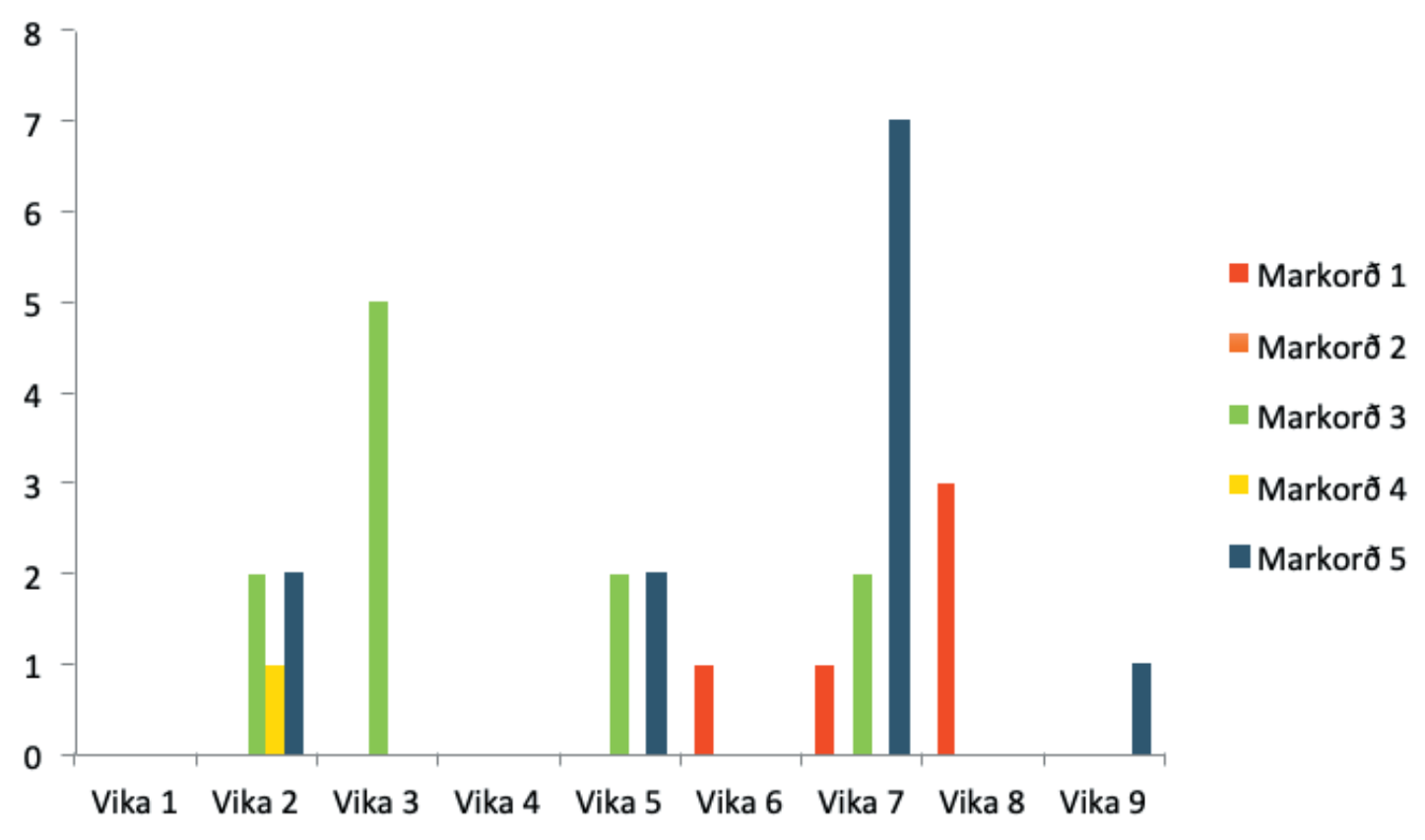

Mynd 2. Fjöldi sjálfsprottinna markorða hjá Gunnari í hverjum tíma

Eins og sjá má eru pað aðallega prjú orðanna fimm (nafn barns, lest og jógúrt) sem komu fram hjá Gunnari, markorð 4 (leikskóli) sagði hann einu sinni sjálfsprottið og markorð 2 (brunabíll) kom aldrei fyrir. Ekki er hægt að sjá augljóst mynstur í notkun sjálfsprottinna markorða hjá Gunnari yfir pjálfunartímabilið, pótt ákveðnum tindi hafi verið nád í sjöundu viku. Dó má sjá að hann sagði fleiri orð sjálfsprottið á seinni hluta meðferðartímabilsins, eða 17 orð samanborið við 12 orð á fyrri hluta tímabilsins.

Á Mynd 3 má sjá niðurstöður vikulegra skráninga foreldra á markorðum og samanburðarorðum, par sem foreldrar skráðu pau markorð og samanburðarorð sem Gunnar sagði sjálfsprottið heima yfir vikuna. Foreldrar skráðu orðin yfir átta vikna tímabil, en ein skráning skilaði sér ekki, sú síðasta, og pví má sjá sjö vikur á myndinni. Bæði markorð og samanburðarorð eru skráð.

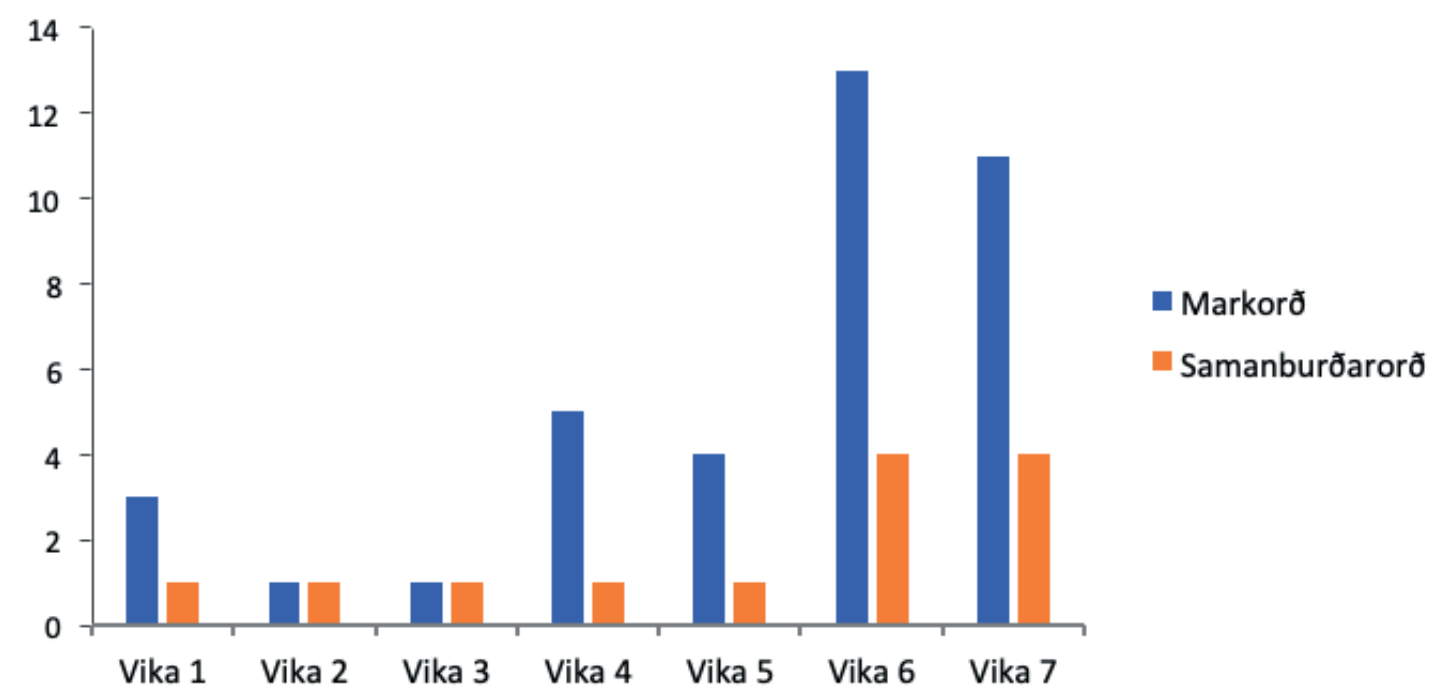

Mynd 3. Heildarfjöldi sjálfsprottinna markorða og samanburðarorða sem komu fyrir hjá Gunnari heima við yfir meðferðartímabilið 
Eins og sjá má notaði Gunnar bæði markorð og samanburðarorð heima við, pótt hann hafi notað markorðin meira. Markorð sagði hann samtals 38 sinnum en samanburðarorð samtals 13 sinnum. Greinilegt er að notkun hans á orðunum jókst eftir pví sem leið á meðferðartímabilið. Bæði notaði hann fleiri orð í sjöttu og sjöundu viku, í samanburði við fyrstu og aðra viku, og sagði pau einnig oftar.

\section{Meðferðarheldni}

Líkt og fjallað var um hér að framan var lagt upp með að meðferðartímarnir yrðu fjórtán talsins og gekk pað eftir. Pá var lögð áhersla á að hvert og eitt orð sem pjálfað var kæmi a.m.k. 64 sinnum fyrir hjá rannsakanda í hverjum meðferðartíma. Tímarnir voru teknir upp á myndband og viðmiðum um ákefð fylgt eftir með pví að skoða myndböndin eftir á og skrá hversu oft hvert markorð kom fyrir. Dar sem hver orðahópur var pjálfaður sjö sinnum, prjú orð í einum tíma og tvö í peim næsta og pannig til skiptis, er um samtals sjö tíma að ræða fyrir hvern orðahóp. Á Mynd 4 má sjá pessa skráningu.

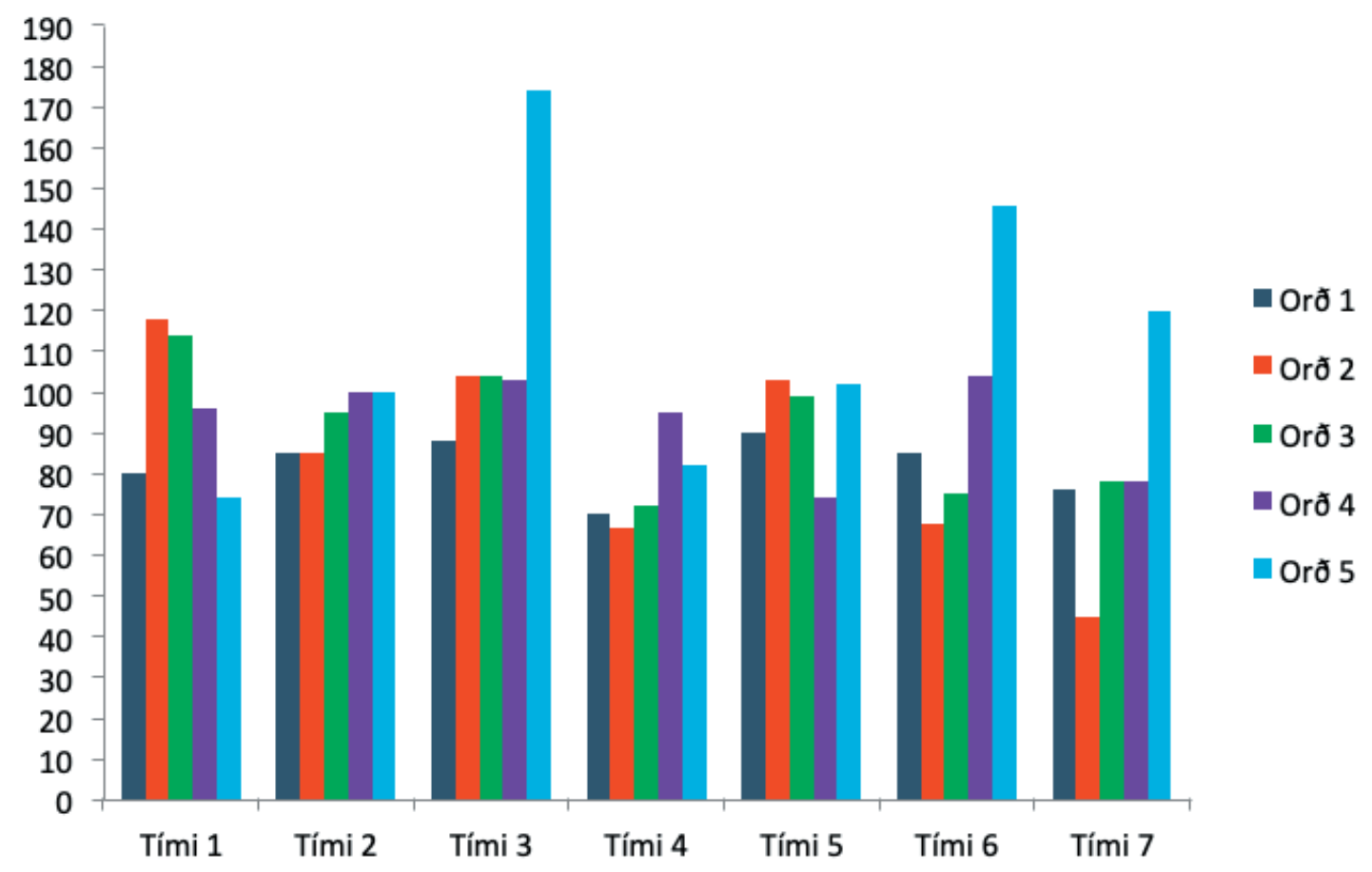

Mynd 4. Fjöldi sagðra markorða hjá rannsakanda í hverjum tíma

Líkt og sjá má kom pað fyrir í einum tíma að eitt orðanna kom aðeins fyrir 45 sinnum hjá rannsakanda, og náðist pví ekki tilsett viðmið. Annars náðist viðmið um að hvert orði kæmi fyrir a.m.k. 64 sinnum í hverjum meðferðartíma. Gert var áreiðanleikamat par sem óháður aðili var fenginn til pess að fara yfir myndbönd úr tveimur pjálfunartímum. Myndböndin voru valin af handahófi. Samtals voru fimm orð pjálfuð í pessum tveimur tímum og leiddu niðurstöður talningar í ljós að hvert og eitt pessara orða kom fyrir hjá rannsakanda oftar en 64 sinnum. Reiknað var samræmi á milli mælinga rannsakanda og mælinga óháða aðilans, reyndist pað vera um 93\% (83-98\%).

Hvað fjölbreytileika íhlutunarinnar varðar var pað markmið rannsakanda að nota fjölbreyttar setningagerðir og margvíslegar aðferðir við að leggja orðin fyrir. Dessi viðmið voru ekki mæld sérstaklega og pví huglægt mat rannsakanda hverju sinni. Dví verður ekki hægt að leggja fram tölulegar niðurstöður sem snúa að fjölbreytileika. 


\section{Umræða}

Helstu niðurstöður rannsóknarinnar voru pær að að almennur orðaforði Gunnars, sem mældur var með málproskaprófinu Orðaskil, jókst yfir meðferðartímabilið umfram pað sem vænta mátti vegna almenns proska. Ekki náðist að prófa markorð og samanburðarorð eins og lagt hafði verið upp með, en aðrar mælingar sem gerðar voru á peim orðum leiddu í ljós að Gunnar notaði markorð meira en samanburðarorð yfir meðferðartímabilið. Pá jókst einnig notkun hans á peim orðum eftir pví sem leið á. Sú aukning í orðaforða sem átti sér stað yfir íhlutunartímabilið hélst mánuði eftir íhlutun og gott betur, en töluvert hægði á orðaforðatileinkuninni eftir að íhlutun lauk ef miðað er við fjölda orða sem hann tileinkaði sér.

\section{Orðaforði}

Fyrsta rannsóknarspurningin fjallaði um hvort almennur orðaforði Gunnars myndi aukast að pjálfun lokinni, umfram pað sem vænta mátti vegna almenns proska. Almennur orðaforði Gunnars var mældur með málproskaprófinu Orðaskil, par sem kafli I-A, Orðaforðagátlisti, er sá hluti prófsins sem snýr að almennum orðaforða. Orðaforði Gunnars jókst töluvert frá pví við upphaf íhlutunar og pangað til íhlutun lauk, eða um 157 orð. Detta eru að meðaltali 17,4 orð á viku yfir níu vikna tímabil. Degar skoðuð eru meðaltöl fyrir pað aldursbil sem Gunnar fellur undir fyrir íhlutun, sem er 30-31 mánaða, og svo aldursbilið sem hann fellur undir eftir íhlutun, sem er 32-33 mánaða, má sjá að meðaldrengur bætir við sig 48 orðum á milli pessara tveggja aldursbila. Af pessu má draga pá ályktun að rúmlega 2/3 af peim orðafjölda sem Gunnar bætti við sig meðan á meðferðinni stóð megi rekja til pjálfunarinnar. Framangreindar niðurstöður eru í samræmi við niðurstöður rannsóknar Alt og félaga (2014), en börnin í peirri rannsókn bættu við sig að meðaltali 21,6 orði á viku meðan á meðferð stóð, mælt með stöðluðu málproskaprófi, en pað er nokkuð sambærilegt við pað sem Gunnar bætti við sig. Í rannsókn Rescorla og félaga (2000) var fylgst með fjölda orða sem börn, sem voru skilgreind sein til máls, tileinkuðu sér á aldrinum tveggja til priggja ára en pau fengu enga íhlutun. Reyndust pað vera að meðaltali 5,6 orð á viku hjá peim börnum sem voru fljót að læra (e. fast learners) og 3,6 orð á viku hjá peim börnum sem voru lengur að læra (e. slower learners). Detta eru mun færri orð á viku en sá orðafjöldi sem börnin í rannsókn Alt og félaga (2014) tileinkuðu sér meðan á íhlutun stóð og einnig mun færri orð en Gunnar tileinkaði sér yfir meðferðartímabilið í peirri íhlutun sem hér um ræðir. Í fleiri rannsóknum er hægt að skoða sambærileg meðaltöl, t.d. hjá börnunum í rannsókn Fernald og Marchman (2012) sem voru á aldrinum 18-30 mánaða og sein til máls. Par var ekki um íhlutun að ræða en pau bættu við sig að meðaltali 7,5 nýjum orðum á viku sem eru aðeins fleiri orðá viku en börnin í rannsókn Rescorla og félaga (2000) gerðu. Degar horft er til pessara rannsókna á orðaforðatileinkun ungra barna sem hér hefur verið minnst á og pær skoðaðar í samhengi við pá aukningu á orðaforða sem varð hjá Gunnari meðan á íhlutun stóð má draga pá ályktun að pá miklu aukningu í orðaforða sem varð hjá Gunnari megi rekja til íhlutunarinnar.

Рað má pví gera ráð fyrir að með pjálfuninni hafi Gunnar lært ákveðnar aðferðir, sem byggðu á fjölbreytileika og ákefð, við að tileinka sér orð. Pessar aðferðir nýtti hann sér svo við að læra ný orð utan pjálfunartímanna. Yfirfærsla af pessu tagi eða hreinlega að læra ný orð fyrir utan pjálfun hlýtur almennt að vera tilgangur með pjálfun orðaforða eins og hér hefur verið lýst. Dað var einmitt tilgáta Alt og félaga (2014) sem er fyrirmynd peirrar rannsóknar sem hér um ræðir. Pá er ákefð hugsanlega vanmetinn páttur í pjálfun barna sem eru sein til máls en fáar rannsóknir eru til sem hægt er að styðjast við í peim efnum. Í pessari íhlutun var lagt upp með að hvert orð kæmi a.m.k. fyrir 64 sinnum í hverjum tíma, en Alt og félagar (2014) byggðu pessa tölu á niðurstöðum rannsóknar Camarata o.fl. (1994).

Drátt fyrir pessar miklu framfarir á stuttum tíma var Gunnar samt enn aðeins undir meðaltali jafnaldra eftir íhlutun, pótt bilið á milli hans og jafnaldra hefði minnkað. Fyrir íhlutun var hann tæpum tveimur staðalfrávikum fyrir neðan meðaltal en eftir íhlutun var hann rúmu staðalfráviki fyrir neðan meðaltal. Dessar niðurstöður eru í samræmi við niðurstöður fleiri erlendra rannsókna 
á íhlutun fyrir börn undir priggja ára aldri sem eru sein til máls, en pær hafa leitt í ljós að meðferð fyrir börn á pessum aldri er áhrifarík leið til bættrar frammistöðu á stöðluðum málproskaprófum (Cable og Domsch, 2011). Pó ber að nefna að prátt fyrir góðan árangur pjálfunar og bættrar frammistöðu í kjölfarið á stöðluðum prófum dugir slíkt ekki til að eyða bilinu á milli pessara barna og jafnaldra (Marulis og Neuman, 2013) sem er einmitt tilfellið í tilviki Gunnars. Degar viðhaldsmælingar voru gerðar, fjórum vikum eftir að íhlutun lauk, var Gunnar tæpu einu staðalfráviki fyrir neðan meðaltal jafnaldra og hafði pá bætt við sig 41 orði síðan við lok íhlutunar. Đær framfarir sem áttu sér stað eftir að íhlutun lauk voru ekki jafn miklar og meðan á íhlutun stóð heldur meira í takt við pað sem vænta má vegna almenns proska, í pað minnsta hjá börnum með dæmigerðan málproska.

\section{Markorð og samanburðarorð}

Önnur rannsóknarspurningin sneri að pví hvort Gunnar myndi læra fleiri markorð en samanburðarorð. Kunnáttan á markorðunum og samanburðarorðunum var mæld með prófi sem sérstaklega var hannað af rannsakanda fyrir pessa rannsókn, en slík próf geta reynst vel par sem pau mæla einmitt pann orðaforða sem verið er að vinna með í hverri rannsókn fyrir sig (Marulis og Neuman, 2010). Prófunin fólst í pví að sýna Gunnari myndir af peim orðum sem um ræddi og reyna að laða fram hjá honum svör við pví hvað petta væri. Detta próf var lagt fyrir Gunnar 1 hverjum pjálfunartíma og einnig mánuði eftir að pjálfun lauk. Engar niðurstöður fengust úr pessum mælingum par sem Gunnar svaraði spurningum rannsakanda aldrei ,rétt", p.e. pau orð sem reynt var að laða fram komu aldrei frá Gunnari pegar hann var spurður. Рað gæti hafa verið af pví að hann vissi ekki hverju hann átti að svara eða að hann vildi ekki svara spurningum um heiti orða pegar hann var spurður. Reyndist pessi mæling bví ekki hentug í pessari rannsókn, pótt slíkar mælingar hafi reynst gagnlegar í mörgum rannsóknum (Marulis og Neuman, 2010) og má par t.d. nefna rannsókn Alt og félaga (2014).

Markorð og samanburðarorð og notkun Gunnars á peim var pó einnig skoðuð með öðrum hætti. Rannsakandi skráði hjá sér pau markorð og samanburðarorð sem Gunnar sagði sjálfsprottið í pjálfunartímum, en par sem engin samanburðarorð komu fram voru aðeins markorð skráð. Degar rýnt er í pær niðurstöður má sjá að á seinni hluta meðferðartímabilsins sagði Gunnar fleiri orð sjálfsprottið en á fyrri hluta tímabilsins. Pá er einnig áhugavert að skoða að pau orð sem hann sagði mest eru pau orð sem höfðu fæest atkvæði, en orðið sem hann sagði oftast sjálfsprottið var eina eins atkvæðis orðið í pjálfuninni (lest). Раð orð sem hann sagði næstoftast er pað sem var næststyst, eða tveggja atkvæða orð (jógúrt). Á eftir pví orði kemur svo hans eigið nafn, sem er priggja atkvæða. Pau tvö orð sem pá eru eftir eru bæði priggja atkvæða, annað peirra sagði hann aldrei sjálfsprottið í pjálfun og hitt sagði hann einu sinni sjálfsprottið. Af pessu má draga pá ályktun að Gunnar hafi átt auðveldara með pau orð sem voru styttri, sem er mjög rökrétt. Einnig átti hann auðveldara með sitt eigið nafn en hin priggja atkvæða orðin sem pjálfuð voru, enda heyrir hann pað orð mun oftar í daglegu tali en önnur orð, eðli málsins samkvæmt. Í ljósi pessara niðurstaðna má velta fyrir sér hvort betra hefði verið að velja styttri orð en gert var, p.e. að hafa ekki prjú af alls fimm markorðum priggja atkvæða. Foreldrar völdu pau orð sem peir töldu mikilvægt fyrir barnið að geta sagt og höfðu enn fremur áhuga barnsins í huga. Sampykkti rannsakandi pau orð án sérstakra athugasemda. Mögulega hefði Gunnari gengið betur að tileinka sér markorðin, og pá jafnvel líka að svara prófspurningunum sem voru lagðar fyrir hann í hverjum tíma, ef orðin hefðu verið styttri. Detta er vert er að hafa í huga ef rannsókn svipuð pessari verður endurtekin. 
Foreldrar skráðu sjálfsprottna notkun Gunnars á markorðum og samanburðarorðum heima fyrir. Ákveðið mynstur kom fram í peirri skráningu par sem Gunnar notaði markorð meira en samanburðarorð. Pá jókst notkun hans á orðunum eftir pví sem leið á pjálfunartímabilið, en hann notaði bæði fleiri markorð og samanburðarorð á seinni hluta pjálfunartímabilsins. Dessar niðurstöður má sjá á Mynd 3. Í rannsókn Alt og félaga (2014) notuðu pátttakendur fleiri markorð en samanburðarorð yfir meðferðartímabilið og átti pað við um allar aðstæður. Detta rímar við notkun Gunnars á markorðum og samanburðarorðum par sem hann notaði markorðin meira en samanburðarorðin, bæði í pjálfunartímum og heima.

\section{Viðhaldsmæling}

Driðja og síðasta rannsóknarspurningin sneri að pví hvort sú aukning sem yrði á orðaforða Gunnars á meðferðartímanum, ef pað yrði aukning, myndi haldast mánuði eftir íhlutun. Frá pví að íhlutun lauk og par til mánuði seinna, pegar viðhaldsmæling var gerð, jókst orðaforði Gunnars um 41 orð eða að meðaltali um 10,3 orð á viku. Pegar petta er borið saman við meðaltöl jafnaldra á sama aldursbili (Elín Döll Dórðardóttir, 1998) má sjá að pessi aukning er í samræmi við pað sem sjá má á milli aldursbila hjá jafnöldrum með dæmigerðan proska. Hér ber enn og aftur að hafa í huga að Gunnar er seinn til máls. Sú aukning sem varð á orðaforða Gunnars á meðferðartímanum hélst pví mánuði eftir íhlutun og gott betur, en aukningin sem átti sér stað eftir íhlutun og fram að viðhaldsmælingu var meira í takt við pá aukningu sem búast má við hjá börnum á pessu aldursbili.

\section{Ályktanir}

Rannsóknin sem hér var gerð kannaði áhrif orðaforðapjálfunar, sem byggist á fjölbreytileika og ákefð, á orðaforða barns á priðja ári sem seint er til máls. Niðurstöður benda til pess að orðaforðapjálfun af pessu tagi hafi jákvæð áhrif á orðaforðatileinkun hjá barni sem seint er til máls á pann hátt að pað bæti við sig fleiri orðum meðan á íhlutun stendur en hægt er að gera ráð fyrir vegna almenns proska. Eru pær niðurstöður í samræmi við niðurstöður fyrri rannsókna sem hér hefur verið fjallað um. Pá hafði pjálfunin einnig jákvæð áhrif á notkun barnsins á markorðum og samanburðarorðum, pótt ekki hafi verið hægt að fullyrða sem svo að pær framfarir hafi komið til vegna pjálfunarinnar. 


\section{Late talkers: Vocabulary intervention for a three year old}

Late talkers are children who have low expressive vocabulary and/or do not use two word sentences at the age of two years. Approximately $15 \%$ of children between 2 and 3 years of age are classified as late talkers and at risk of developing language disorder. Developmental language disorder (DLD) in children is characterized by problems with language that cannot be explained by neurological, cognitive, sensory or emotional factors. The prevalence of DLD in five year old children is approximately $7 \%$. Around half of the children identified as late talkers will later acquire language within the normal range but approximately half of the others will later be diagnosed with language disorder. At the age of two years it is not known which children will later be diagnosed with DLD. Language disorders may cause social and learning problems later in life. Early intervention, where a child receives appropriate evidence based intervention, can have positive effects on language development. Almost all children in Iceland attend preschool between the ages of 2 and 3 and spend on average seven hours in school each day, five days a week. Preschool teachers play a key role in advising and educating parents on language development. However, they do not have an official role in systematically screening early language to identify children at risk of being late talkers. Additionally, early intervention for children under three years of age is not systematically organized. Intervention for this age group is limited in Iceland. Early intervention for young children needs to be defined and organized so that each child can be serviced according to his/her needs.

The aim was to investigate whether a cross-situational learning method was successful to improve vocabulary knowledge in a late talker. The intervention was based on the presentation of a few predetermined target words administered with intensity using a different variable method. The subject heard the target words 64 times or more in each session. Control words were also chosen but not presented during therapy sessions. The intervention was delivered twice weekly by the first author within the child's preschool for a total of fourteen sessions over a period of nine weeks. The duration of each treatment session was about 30 minutes.

Increase in vocabulary was measured by the standardized language development test Ordaskil, which is the Icelandic version of the MacArthur Communicate Development Inventory. Results showed an increase beyond what is to be expected in a child with normal development. During the intervention period the mean increase of vocabulary was 17.4 words each week or 157 words over the nine weeks of intervention. Vocabulary knowledge changed from being two standard deviations from the mean of children at his age to being slightly below one standard deviation from the mean. Results from target and control word testing were not of significance. However, other measures showed that the child used target words more than control words, both at home and in intervention sessions. Words of one and two syllables were used more frequently than longer words. His use of the words in daily life also increased over the intervention period. The child further added 41 words to his vocabulary knowledge during the month after intervention which is approximately the same number of words as children add with typical language development at his age. These norms are based on the Ordaskil measure. This suggests that the child maintained vocabulary gains one month from intervention.

It is important to identify delay in language development as early as possible. After identifying a late talker, appropriate stimulation or intervention needs to be applied. This study suggests that vocabulary intervention can be beneficial. This is the first time a study of this kind is implemented in Iceland.

Key words: Language development, late talkers, vocabulary, early intervention. 


\section{Um höfundana}

Marta Eydal (martaeydal@gmail.com) er talmeinafræðingur og starfar á Landspítala Háskólasjúkrahúsi. Marta lauk MS-prófi í talmeinafræði frá Háskóla Íslands árið 2018 og BA-prófi í almennum málvísindum frá Háskóla Íslands árið 2013.

Jóhanna T. Einarsdóttir (jeinars@hi.is) er talmeinafræðingur og dósent við Háskóla Íslands á Mennta- og Heilbrigðisvísindasviði. Hún lauk doktorsprófi frá Háskóla Íslands, Læknadeild, árið 2009. Rannsóknir Jóhönnu hafa beinst að máltöku barna á leikskólaaldri, bæði mælingar á málproska og íhlutun. Hún hefur einnig rannsakað stam, greiningu pess og meðferð hjá öllum aldurshópum.

Porlákur Karlsson (thorlakur@ru.is) er sálfræðingur og dósent í sálfræði við Háskólann í Reykjavík. Hann er með doktorspróf í sálfræði frá WestVirginia University (1990) með atferlisgreiningu sem aðalgrein en tölfræði og aðferðafræði sem aukagrein. Rannsóknir hans eru helst á sviði aðferðafræði rannsókna og launamunar kynja.

Póra Sæunn Úlfsdóttir (Thora.Saeunn.Ulfsdottir@reykjavik.is) er talmeinafræðingur og ráðgjafi hjá Miðju máls og læsis, Skóla- og frístundasviði Reykjavíkurborgar. Hún lauk MS-prófi í talmeinafræði árið 1986. Dóra Sæunn lauk viðbótardiplómanámi við Háskóla Íslands í náms- og kennslufræði á kjörsviði máls og læsis sumarið 2018. Póra Sæunn hefur verið stundakennari við Mennta- og Heilbrigðisvísindasvið Háskóla Íslands frá 2008.

\section{About the authors}

Marta Eydal (martaeydal@gmail.com) is a speech-language pathologist working at The National University Hospital of Iceland. Marta completed an MS degree in speech-language pathology from the University of Iceland in 2018 and a BA degree in general linguistics from the University of Iceland in 2013.

Jóhanna T.Einarsdóttir (jeinars@hi.is) is an associate professor at the University of Iceland School of Education and School of Health Sciences. She received her PhD in 2009 from the Medical department at the University of Iceland. Jóhanna has been investigating children's language acquisition in early childhood, measurements as well as intervention. Her special interests are fluency disorders, stuttering and stuttering treatment.

Thorlakur Karlsson (thorlakur@ru.is) is a psychologist and an associate professor at Reykjavik University. He has a doctoral degree in psychology from West Virginia University (1990), with a major in behavior analysis and a minor in statistics and methodology. His research is mainly in the area of methodology and gender wage difference.

Thora S.Ulfsdottir (Thora.Saeunn.Ulfsdottir@reykjavik.is) is a speech language pathologist and an educational consultant at the Center of Language and Literacy, at Reykjavik City Department of Education and Youth. She received her M.S.-CCC degree in 1986 and completed a Postgraduate Diploma from University of Iceland with emphasis on Language and Literacy in 2018. She has been a part time teacher at the University of Iceland School of Education and School of Health Sciences since 2008. 


\section{Heimildir}

Alt, M., Meyers C. og Ancharski, A. (2012). Using principles of learning to inform language therapy design for children with specific language impairment. International Journal of Language $\mathcal{E}$ Communication Disorders, 47(5), 487-498. https:// doi.org/10.1111/j.1460-6984.2012.00169.x

Alt, M., Meyers, C., Oglivie, T., Nicholas, K. og Arizmendi, G. (2014). Cross-situational statistically-based word learning intervention for late-talking toddlers. Journal of Communication Disorders, 52, 207-220. https://doi.org/10.1016/j. jcomdis.2014.07.002

Bishop, D.V. og Edmundson, A. (1987). Language-impaired 4-year-olds: Distinguishing transient from persistent impairment. Journal of Speech and Hearing Disorders, 52(2), 156-173. https://doi.org/10.1044/jshd.5202.156

Bishop, D.V., North, T. og Donlan, C. (1995). Genetic basis of specific language impairment: Evidence from a twin study. Developmental Medicine and Child Neurology, 37(1), 56-71. https://doi.org/10.1111/j.1469-8749.1995.tb11932.x

Bishop, D. V., Price, T. S., Dale, P. S. og Plomin, R. (2003). Outcomes of early language delay: II. Etiology of transient and persistent language difficulties. Journal of Speech, Language and Hearing Research, 46, 561-575. https://doi. org/10.1044/1092-4388(2003/045)

Bredin-Oja, S. L. og Fey, M. E. (2014). Children's responses to telegraphic and grammatically complete prompts to imitate. American Journal of Speech-Language Pathology, 23(1), 15-26. https://doi.org/10.1044/1058-0360(2013/12-0155)

Butler, C., Brown, J.A. og Woods, J.J. (2014). Teaching at-risk toddlers new vocabulary using interactive digital storybooks. Contemporary Issues in Communication Science and Disorders, 41,155-168. 1092-5171/14/4102-0155

Cable, A. L. og Domsch, C. (2011). Systematic review of the literature on the treatment of children with late language emergence. International Journal of Language \& Communication Disorders, 46(2), 138-154.10.3109/13682822.2010.487883

Camarata, S. M., Nelson, K. E. og Camarata, M. N. (1994). Comparison of conversational-recasting and imitative procedures for training grammatical structures in children with specific language impairment. Journal of Speech, Language and Hearing Research, 37, 1414-1423. https://doi.org/10.1044/jshr.3706.1414

Carson, C. P., Klee, T., Carson, D. K. og Hime, L. K. (2003). Phonological profiles of 2-year-olds with delayed language development: Predicting clinical outcomes at age 3. American Journal of Speech-Language Pathology, 12(1), 28-39. https:// doi.org/10.1044/1058-0360(2003/050)

Conti-Ramsden, G., Durkin, K., Simkin, Z. og Knox, E. (2009). Specific language impairment and school outcomes. I: Identifying and explaining variability at the end of compulsory education. International Journal of Language $\&$ Communication Disorders, 44(1), 15-35. https://doi.org/10.1080/13682820801921601

Dale, P. S., Price, T. S, Bishop, D.V. og Plomin, R. (2003). Outcomes of early language delay: I. Predicting persistent and transient language difficulties at 3 and 4 years. Journal of Speech, Language and Hearing Research, 46(3), 544-560. https:// doi.org/10.1044/1092-4388(2003/044)

Desmaris, C., Sylvestre,A., Meyer, F., Bairati, I. og Rouleau, N. (2008). Systematic review of the literature on characteristics of late-talking toddlers. International Journal of Language \& Communication Disorders, 43(4), 361-389.

DeVeney, S. L., Cress, C.J. og Reid, R. (2014). Comparison of two word learning techniques and the effect of neighborhood density for late talkers. Communication Disorders Quarterly, 35(3),133-145. https://doi.org/10.1177/1525740113516788

Durkin, K. og Conti-Ramsden, G. (2007). Language, social behavior, and the quality of friendships in adolescents with and without a history of specific language impairment. Child Development, 78(5), 1441-1457. https://doi. org/10.1111/j.1467-8624.2007.01076.x

Einarsdóttir, J. T., Björnsdóttir, A. og Símonardóttir, I. (2016). The predictive value of preschool language assessments on academic achievement: A 10-year longitudinal study of Icelandic children. American Journal of Speech-Language Pathology, 25(1), 67-79. https://doi.org/10.1044/2015_AJSLP-14-0184

Elín Döll Dórðardóttir. (1998). Orðaskil: Mállroskapróf: Leiðbeiningar og aldursviðmið. Reykjavík: Framsaga, dreifing Talpjálfun Reykjavíkur.

Embætti landlæknis. (2013). Ung- og smábarnavernd, leiðbeiningar um heilsuvernd barna 0-5 ára. Sótt af https://rafhladan.is/ bitstream/handle/10802/11352/2ungbarnavernd_leidbeiningar_12.05.13.pdf?sequence $=1$

Ervin, M. (2001). SLI: What we know and why it matters. The ASHA Leader, 6(12), 4-31. https://doi.org/10.1044/ leader.FTR1.06122001.4

Fernald,A. og Marchman,V.A. (2012). Individual differences in lexical processing at 18 months predict vocabulary growth in typically developing and late-talking toddlers. Child Development, 83(1), 203-222. doi: 10.1177/0956797613488145

Guðrún Árnadóttir og Porlákur Karlsson. (2003). Einliðasnið: Öflug leið til samhæfingar klínískrar vinnu og rannsókna. Í Sigríður Halldórsdóttir og Kristján Kristjánsson (ritstjórar), Handbók í aðferðafređð og rannsóknum í heilbrigðisvísindum (bls. 295-330). Akureyri: Háskólinn á Akureyri. 
Hammer, C. S., Morgan, P., Farkas, G., Hillemeier, M., Bitetti, D. og Maczuga, S. (2017). Late talkers: A population-based study of risk factors and school readiness consequences. Journal of Speech, Language and Hearing Research, 60(3), 607-626. https://doi.org/10.1044/2016_JSLHR-L-15-0417

Horner, R. H., Carr, E. G., Halle, J., McGee, G., Odom, S. og Wolery, M. (2005). The use of single-subject research to identify evidence-based practice in special education. Exceptional Children, 71(2), 165-179. https://doi. org/10.1177/001440290507100203

Horwitz, S. M., Irwin, J. R., Briggs-Gowan, M. J., Bosson Heenan, J. M., Mendoza, J. og Carter, A. S. (2003). Language delay in a community cohort of young children. Journal of American Academy of Child and Adolescent Psychiatry, 42(8), 932-940. https://doi.org/10.1097/01.CHI.0000046889.27264.5E

Hrafnhildur Ragnarsdóttir,Jóhanna Einarsdóttir, Marta Gall Jörgensen og Póra Sæunn Úlfsdóttir. (2012). Skýrsla um stöðu barna og ungmenna með tal-og málproskaröskun. Sótt af http://www.althingi.is/altext/140/s/pdf/1088.pdf

Höskuldur Práinsson. (1995). Handbók um málfraði. Reykjavík: Námsgagnastofnun.

Jóhanna T. Einarsdóttir og Álfhildur Porsteinsdóttir. (2015). Málsýni leikskólabarna:Aldursbundin viðmið. Netla-Veftímarit um uppeldi og menntun. Sótt af http://netla.hi.is/greinar/2015/ryn/010.pdf

Marulis, L. M. og Neuman, S. B. (2010). The effects of vocabulary intervention on young children's word learning: A meta-analysis. Review of Educational Research, 80(3), 300-335. https://doi.org/10.3102/0034654310377087

Marulis, L. M. og Neuman, S. B. (2013). How vocabulary interventions affect young children at risk: A meta-analytic review. Journal of Research on Educational Effectiveness, 6(3),223-262. https://doi.org/10.1080/19345747.2012.755591

Norbury, C. F., Gooch, D., Wray, C., Baird, G., Charman, T., Simonoff, E. . . Pickles, A. (2016). The impact of nonverbal ability on prevalence and clinical presentation of language disorder: Evidence from a population study. Journal of Child Psychology and Psychiatry, 57(11), 1247-1257. https://doi.org/10.1111/jcpp.12573

Perry, L. K., Samuelson, L. K., Malloy. L. M. og Schiffer, R. N. (2010). Learn locally, think globally: Exemplar variability supports higher-order generalization and word learning. Psychological Science, 21(12), 1894-1902. https://doi. org/10.1177/0956797610389189

Ramey, C. T. og Ramey, S. L. (1998). Early intervention and early experience. American Psychologist, 53(2), 109-120. http://dx.doi.org/10.1037/0003-066X.53.2.109

Reilly, S., Bavin, E., Bretherton, L., Conway, L., Eadie, P., Cini, E., ...Wake, M. (2009). The early language inVictoria study (ELVS):A prospective, longitudinal study of communication skills and expressive vocabulary development at 8,12 and 24 months. International Journal of Speech Language Pathology, 11(5), 344-357. https://doi.org/10.1080/17549500903147560

Rescorla, L. (1989). The Language Development Survey: A screening tool for delayed language in toddlers. Journal of Speech and Hearing Disorders, 54(4), 587-599. https://doi.org/10.1044/jshd.5404.587

Rescorla, L. (2011). Late talkers: Do good predictors of outcome exist? Developmental Disabilities Research Reviews, 17, 141-150. https://doi.org/10.1002/ddrr.1108

Rescorla, L., Mirak, J. og Singh, L. (2000).Vocabulary growth in late talkers: lexical development from 2;0 to 3;0. Journal of Child Language, 27(2), 293-311.

Rescorla, L., Roberts, J. og Dahlsgaard, K. (1997). Late talkers at 2: Outcome at age 3. Journal of Speech, Language, and Hearing Research, 40(3), 556-566. https://doi.org/10.1044/jslhr.4003.556

Rice, M. L. (2012). Toward epigenetic and gene regulation models of specific language impairment: looking for links among growths, genes, and impairments. Journal of Neurodevelopmental Disorders, 4(27), 1866-1955. https://doi. org/10.1186/1866-1955-4-27

Saffran, J. R., Aslin, R. N. og Newport, E. L. (1996). Statistical learning by 8-month-old infants. Science, 274(5294), 1926-1928. DOI: 10.1126/science.274.5294.1926

Smith, A. D. og Smith, K. (2012). Cross-situational learning. Í N. Seel (ritstjóri) Encyclopedia of the Sciences of Learning (bls. 864-866). Boston, MA: Springer US.

Snowling, M., Bishop, D.V. og Stothard, S. E. (2000). Is preschool language impairment a risk factor for dyslexia in adolescence? Journal of Child Psychology and Psychiatry, 41(5), 587-600.

Strong, R. W., Silver, H. F., Perini, M. J. og Tuculescu, G. M. (2014). Reading for academic success: Powerful strategies for struggling, average, and advanced readers, grades 7-12. Thousand Oaks, CA: Corwin Press.

Thal, D. J. og Tobias, S. (1992). Communicative gestures in children with delayed onset of oral expressive language use. Journal of Speech and Hearing Research, 35(6), 1281-1289. https://doi.org/10.1044/jshr.3506.1289

Thordardottir, E. T. og Weismer, S. E. (1998). Mean length of utterance and other language sample measures in early Icelandic. First Language, 18(52), 1-32. DOI:10.1177/014272379801805201

Tomblin, J. B., Records, N. L., Buckwalter, P., Zhang, X., Smith, E. og O’Brien, M. (1997). Prevalence of specific language impairment in kindergarten children. Journal of Speech, Language, and Hearing Research, 40(6), 1245-1260. https://doi. org/10.1044/jslhr.4006.1245 
Tsybina, I. og Eriks-Brophy, A. (2007). Issues in research on children with early language delay. Contemporary Issues in Communication Science and Disorders, 34, 118-133. 1092-5171/07/3402-0118

Vigil, D. C., Hodges, J. og Klee, T. (2005). Quantity and quality of parental language input to late talking toddlers during play. Child Language Teaching and Therapy, 21(2), 107-122. https://doi.org/10.1191/0265659005ct284oa

Zubrick, S. R., Taylor, C. L., Rice, M. L. og Slegers, D.W. (2007). Late language emergence at 24 months:An epidemiological study of prevalence, predictors, and covariates. Journal of Speech, Language, and Hearing Research, 50(6), 1562-1592. https://doi.org/10.1044/1092-4388(2007/106)

Marta Eydal, Jóhanna T. Einarsdóttir, Dorlákur Karlsson og Dóra Sæunn Úlfsdóttir. (2019). Börn sem eru sein til máls: Áhrif pjálfunar á orðaforða barns á priðja ári

Netla - Veftímarit um uppeldi og menntun. Menntavísindasvið Háskóla Íslands.

Sótt af http://netla.hi.is/greinar/2019/ryn/02

DOI: https://doi.org/10.24270/netla.2019.2 